\title{
Pengaruh Motivasi Kerja dan Kepuasan Kerja terhadap Peningkatan Produktivitas Kerja Karyawan
}

\section{The Influence of Work Motivation and Job Satisfaction toward Increased Employee Productivity}

\author{
Ayu Sabena*, Ramadhan Hamdani Harahap**, Usman Tarigan ${ }^{* * *}$ \\ *Magister Program Studi Administrasi Publik, Universitas Medan Area \\ **Fakultas Ilmu Sosial dan Ilmu Politik, Universitas Sumatra Utara, Indonesia \\ ***Fakultas Ilmu Sosial dan Ilmu Politik, Universitas Medan Area \\ Corresponding author: E-mail: ayusabenauma@gmail.com
}

\begin{abstract}
Abstrak
Produktivitas karyawan dapat ditentukan dengan mengukur tingkat motivasi dan kinerja dimana bagian dari ruang lingkup manajemen sumber daya manusia. Konsep produktivitas kerja dapat dilihat dari dua dimensi, yaitu dimensi individu dan dimensi organisasian. Faktor yang mampu mendukung produktivitas karyawan perusahaan adalah motivasi dan kepuasan. Motivasi merupakan suatu dorongan yang membuat seseorang mampu dan rela untuk mengerahkan kemampuan diri dalam suatu organisasi. Kepuasan kerja juga didefenisikan sebagai suatu perasaan positif tentang pekerjaan seseorang yang merupakan hasil dari evaluasi karakteristik. Tujuan penelitian ini adalah untuk menganalisis pengaruh motivasi kerja dan kepuasan kerja terhadap peningkatan produktivitas kerja karyawan dengan menggunakan analisis regresi linier berganda. Dalam penelitian ini digunakan data primer dengan kuisioner sebagai teknik pengambilan sampel. Pengujian hipotesis dengan menggunakan uji $\mathrm{F}$ dan Uji $\mathrm{t}$. Hasil yang diperoleh dari penelitian ini dari uji $\mathrm{F}$ diperoleh nilai sebesar 13,964 dimana terdapat pengaruh signifikan motivasi dan kepuasan, terhadap produktivitas secara simultan. Uji t diperoleh nilai t motivasi sebesar 3,358 dimana terdapat pengaruh signifikan motivasi terhadap produktivitas degan nilai koefisien regresi 0,551 atau 55,1\% sedangkan nilai t kepuasan sebesar 3,260 dimana terdapat pengaruh signifikan kepuasan terhadap produktivitas degan nilai koefisien regresi 0,406 atau 40,6\%.
\end{abstract}

Kata kunci : Regresi linear berganda, Motivasi, Kepuasan kerja, Produktivitas.

\begin{abstract}
Employee productivity can be determined by measuring the level of motivation and job satisfaction in which part of the scope of human resource management. The concept of productivity can be seen from two dimensions, namely the individual dimension and the dimension of the organization. Factors that are capable of supporting the company's motivation employee productivity and satisfaction. Motivation is an impulse that makes a person and willing to exert themselves in the capability of an organization. Job satisfaction also was defined as a positive feelings about the work of someone who is the characteristics of evaluation results. The purpose of this study was to analyze the influence of work motivation and job satisfaction toward increased employee productivity by using multiple linear regression analysis. In this research the primary data used with questionnaire technique of sampling. Hypothesis testing using the $\mathrm{F}$ test and $\mathrm{t}$ test. The results obtained from the research of $\mathrm{F}$ test obtained a value of 13,964 which is significant influence motivation and satisfaction to productivity simultaneously. T test value obtained motivation of 3,358 which is significant influence motivation towards productivity by regression coefficient values 0,551 or $55,1 \%$ while the value or at the satisfaction of 3,260 which is significant influence satisfaction to productivity with a regression coefficient value 0,406 or $40,6 \%$.
\end{abstract}

Keywords: Multivariate Linear Regression, Motivation, Job satisfaction, productivity.

How to Cite: Sabena, A., Ramadhan H.H., Usman T.., (2016), Pengaruh Motivasi Kerja dan Kepuasan Kerja terhadap Peningkatan Produktivitas Kerja Karyawan, Jurnal Administrasi Publik, 6 (2): 137-146. 


\section{PENDAHULUAN}

Kesehatan dan kesejahtraan merupakan hak asasi manusia dan diakui Indonesia. Pengakuan itu tercantum dalam deklarasi perserikatan bangsa-bangsa tahun 1948, tentang hak azasi manusia pasal 25 ayat 1 yang berisi setiap orang berhak atas derajat hidup yang memadai untuk kesehatan dan kesejahtraan dirinya dan keluarganya, termasuk hak atas pangan, pakaian, perumahan dan perawatan kesehatan serta pelayanan sosial yang diperlukan dan berhak atas jaminan pada saat menganggur, menderita sakit, cacat, menjadi seorang janda atau duda hingga mencapai usia lanjut atau keadaan lainnya. Badan Penyelenggara Jaminan Sosial Kesehatan (BPJS) sebagai pihak yang wajib memberikan jaminan sosial kepada rakyat atau pemerintah perlu mengambil kebijakan radikal berupa mobilisasi dana jangka panjang dalam jumlah yang cukup besar secara bertahap.

Besarnya pembayaran kepada fasilitas kesehatan ditentukan berdasarkan kesepakatan antara BPJS kesehatan dan asosiasi fasilitas kesehatan di wilayah tersebut dan mengacu pada tarif standar yang ditentukan oleh menteri kesehatan. BPJS kesehatan wajib menyampaikan pertanggung jawabannya dalam bentuk laporan pengelolaan program dan laporan keuangan tahunan.
Peserta atau pegawai BPJS mendapatkan empat program jaminan kesehatan, untuk tenaga kerja yang sudah terdaftar sebagai peserta BPJS otomatis mendapatkan jaminan kesehatan dimana karyawan telah mendapatkan haknya didalam suatu perusahaan. Jaminan kesehatan saja tidak cukup untuk membuktikan apakah karyawan sudah memenuhi tanggungjawabnya untuk meningkatkan produktivitas yang merupakan salah satu tujuan awal dari perusahaan disebabkan karyawan merupakan tonggak maupun penopang yang kuat dalam meningkatkan produktivitas dan kinerja di dalam suatu perusahaan.

\section{METODE PENELITIAN}

Jenis penelitian ini adalah penelitian eksplanasi asosiatif, yaitu penelitian yang bertujuan untuk mengetahui hubungan antara dua variabel atau lebih (Sugiyono, 2008). Variabel yang dihubungkan dalam penelitian ini adalah Motivasi Kerja ( $\left.\mathrm{X}_{1}\right)$, Kepuasan Kerja $\left(\mathrm{X}_{2}\right)$ dan Produktivitas Kerja Karyawan (Y).

Penelitian ini dilakukan pada Badan Penyelenggara Jaminan Sosial Kesehatan (BPJS) Ketenagakerjaan yang berada di Jalan Gunung Krakatau No. 17 A, Kecamatan Medan Timur. Penelitian ini dilaksanakan mulai bulan Oktober 2016 hingga bulan Mei 2017.

Dalam penelitian ini terdapat tiga variabel yang diteliti, yaitu:

Tabel 2.1. Operasionalisasi variabel

\begin{tabular}{|c|c|c|c|}
\hline Variabel & Definisi Variabel & Indikator & $\begin{array}{l}\text { Skala } \\
\text { Pengukuran }\end{array}$ \\
\hline $\begin{array}{l}\text { Motivasi } \\
\left(\mathrm{X}_{1}\right)\end{array}$ & $\begin{array}{l}\text { Suatu keadaan dalam diri pribadi } \\
\text { setiap karyawan yang } \\
\text { mereka mendorong } \\
\text { pekerjaannya. }\end{array}$ & $\begin{array}{l}\text { Kebutuhan Fisiologi } \\
\text { Kebutuhan Rasa aman } \\
\text { Kebutuhan Sosial } \\
\text { Kebutuhan Penghargaan Diri } \\
\text { Kebutuhan Aktualisasi diri }\end{array}$ & Likert \\
\hline $\begin{array}{l}\text { Kepuasan } \\
\text { (X2) }\end{array}$ & $\begin{array}{l}\text { Suatu perasaan positif tentang } \\
\text { pekerjaan karyawan yang merupakan } \\
\text { hasil dari sebuah } \\
\text { karakteristiknya. }\end{array}$ & $\begin{array}{l}\text { Kemampuan melaksanakan pekerjaan } \\
\text { Berat ringannya pekerjaan } \\
\text { Gaji yang sesuai } \\
\text { Jenjang karir } \\
\text { Promosi jabatan yang adil }\end{array}$ & Likert \\
\hline $\begin{array}{l}\text { Produktiv } \\
\text { itas }(\mathrm{Y})\end{array}$ & $\begin{array}{l}\text { kemampuan memperoleh manfaat } \\
\text { yang sebesar-besarnya dari sarana dan } \\
\text { prasarana yang tersedia dengan } \\
\text { menghasilkan output yang optimal } \\
\text { bahkan kalau mungkin yang maksimal. }\end{array}$ & $\begin{array}{l}\text { Kuantitas } \\
\text { Kualitas } \\
\text { Hasil kerja } \\
\text { Kehadiran } \\
\text { Kemampuan Bekerjasama }\end{array}$ & Likert \\
\hline
\end{tabular}


Penelitian ini menggunakan skala likert, yaitu digunakan untuk mengukur sikap, pendapat, dan persepsi seseorang atau sekelompok orang tentang sesuatu fenomena sosial (Sugiyono, 2008). Dalam penelitian ini, peneliti memberikan lima alternatif jawaban kepada responden dengan menggunakan skala 1 sampai dengan 5 yang dapat dilihat pada tabel berikut ini:

Tabel 2.2. Instrumen skala Likert

\begin{tabular}{llll}
\hline No & Pertanyaan & & Skor \\
\hline 1 & Sangat Setuju & SS & 5 \\
2 & Setuju & S & 4 \\
3 & Netral & N & 3 \\
4 & Tidak Setuju & TS & 2 \\
5 & Sangat Tidak Setuju & STS & 1 \\
\hline
\end{tabular}

Sumber : Sugiyono (2008)

Populasi penelitian ini adalah seluruh karyawan Badan Penyelenggara Jaminan Sosial Kesehatan (BPJS) Ketenagakerjaan yang berjumlah 37 orang. Populasi ini bersifat heterogen yang dapat dilihat dari beragamnya usia, jenis kelamin, dan pendidikan.

Teknik sampling yang diuraikan dalam penelitian ini adalah sampling jenuh ialah teknik pengambilan sampel apabila semua populasi digunakan sebagai sampel. Sampel dalam penelitian ini berjumlah 37 orang karyawan Badan Penyelenggara Jaminan Sosial Kesehatan (BPJS) Ketenagakerjaan. Penelitian ini menggunakan 3 metode yaitu observasi, wawancara dan kuesioner.

\section{HASIL DAN PEMBAHASAN}

Tabulasi mengenai karakteristik responden yang berjumlah 37 orang, di distribusikan sebagai berikut:

Tabel 3.1.1.Gender responden

\begin{tabular}{lll}
\hline Jenis Kelamin & Jumlah & Presentase \\
\hline Laki-Laki & 15 & $40,5 \%$ \\
Perempuan & 22 & $59,5 \%$ \\
T O T A L & 37 & $100 \%$ \\
\hline Sumber:Hasil & Penelitian, 2017 (data \\
)
\end{tabular}

Pada Tabel 3.1.1. menunjukkan bahwa mayoritas responden adalah Laki- Laki dengan presentase sebesar 40,5\%, dan Perempuan sebesar $59,5 \%$.

Tabel 3.1.2. Karakteristik usia responden

\begin{tabular}{lll}
\hline Usia & Jumlah & Presentase \\
\hline 21 - 25 Tahun & 10 & $27 \%$ \\
26-30 Tahun & 18 & $48,6 \%$ \\
>30 Tahun & 9 & $24,4 \%$ \\
T 0 T A L & 37 & $100 \%$ \\
\hline
\end{tabular}

Sumber: Hasil Penelitian, 2017 (data diolah)

Pada Tabel 3.1.2. menunjukkan bahwa mayoritas responden adalah usia $>30$ Tahun dengan presentase sebesar 24,4\%, $26-30$ tahun dengan presentase sebesar $48,6 \%$, dan 21 - 25 Tahun sebesar 27\%.

Hasil yang diperoleh dari uji validitas adalah sebagai berikut:

Tabel 3.2.1. Uji validitas motivasi kerja Item Statistik Total

\begin{tabular}{|c|c|c|c|c|}
\hline & \multicolumn{3}{|c|}{$\begin{array}{l}\text { Rata-rata Variasi Korelasi } \\
\text { skala jikaskala jikatotal }\end{array}$} & $\begin{array}{l}\text { Alfa } \\
\text { Cronbach } \\
\text { jika item } \\
\text { idihapus }\end{array}$ \\
\hline $\mathrm{mk} 1$ & 78,35 & 13,901 & ,877 & ,730 \\
\hline mk2 & 78,54 & 13,700 & ,476 & ,744 \\
\hline mk3 & 79,84 & 15,695 & 328 & ,767 \\
\hline $\mathrm{mk} 4$ & 78,41 & 14,081 & ,652 & ,738 \\
\hline mk5 & 78,35 & 13,901 & , 877 & 730 \\
\hline mk6 & 78,35 & 13,901 & , 877 & ,730 \\
\hline mk7 & 79,16 & 16,306 & 395 & ,759 \\
\hline mk8 & 78,35 & 13,901 & , 877 & ,730 \\
\hline mk9 & 78,57 & 15,086 & 349 & ,763 \\
\hline $\mathrm{mk} 10$ & 78,81 & 13,658 & ,432 & ,749 \\
\hline $\mathrm{mk} 11$ & 78,35 & 13,901 & 877 & ,730 \\
\hline $\mathrm{mk} 12$ & 78,35 & 13,901 & 877 & ,730 \\
\hline mk13 & 79,32 & 14,725 & 333 & ,767 \\
\hline mk14 & 78,70 & 14,048 & 392 & ,765 \\
\hline $\mathrm{mk} 15$ & 79,54 & 15,033 & 378 & ,761 \\
\hline $\mathrm{mk} 16$ & 79,57 & 16,252 & 381 & ,754 \\
\hline $\mathrm{mk} 17$ & 79,68 & 16,336 & , 105 & ,788 \\
\hline $\mathrm{mk} 18$ & 79,95 & 15,164 & 336 & ,766 \\
\hline mk19 & 79,16 & 15,640 & ,326 & ,767 \\
\hline \multicolumn{5}{|c|}{$\begin{array}{l}\text { Tabel 3.2.2.Uji validitas kepuasan kerja } \\
\text { Item Statistik Total }\end{array}$} \\
\hline & $\begin{array}{l}\text { Rata-rat } \\
\text { skala jil } \\
\text { item } \\
\text { terdeksi }\end{array}$ & $\begin{array}{l}\text { Variasi } \\
\text { askala ji } \\
\text { item } \\
\text { dihapus }\end{array}$ & $\begin{array}{l}\text { Korelas } \\
\text { ikatotal } \\
\text { item } \\
\text { dikorek }\end{array}$ & $\begin{array}{l}\text { si Alfa } \\
\text { Cronbach } \\
\text { jika item } \\
\text { ksidihapus } \\
\end{array}$ \\
\hline kk1 & 68,08 & 21,521 & ,326 & ,843 \\
\hline kk2 & 68,08 & 21,243 & ,410 & ,837 \\
\hline kk3 & 67,95 & 21,497 & ,355 & 839 \\
\hline kk4 & 68,22 & 20,285 & ,404 & ,839 \\
\hline kk5 & 68,16 & 21,695 & 377 & ,838 \\
\hline kk6 & 68,27 & 20,536 & 371 & 840 \\
\hline kk7 & 67,43 & 20,697 & ,479 & ,834 \\
\hline kk8 & 67,86 & 20,842 & ,459 & 835 \\
\hline kk9 & 67,38 & 20,464 & ,564 & ,830 \\
\hline kk10 & 68,41 & 21,692 & 329 & ,841 \\
\hline
\end{tabular}




$\begin{array}{lllll}\text { kk11 } & 67,30 & 19,381 & , 816 & , 817 \\ \text { kk12 } & 67,46 & 18,866 & , 800 & , 815 \\ \text { kk13 } & 67,97 & 20,805 & , 554 & , 831 \\ \text { kk14 } & 67,54 & 19,922 & , 552 & , 829 \\ \text { kk15 } & 68,43 & 22,086 & , 341 & , 842 \\ \text { kk16 } & 68,16 & 22,084 & , 725 & , 836 \\ \text { kk17 } & 67,46 & 19,644 & , 632 & , 825\end{array}$

Tabel 3.2.3. Uji validitas produktivitas Item Statistik Total

\begin{tabular}{lllll}
\hline \multicolumn{4}{c}{ Rata-rata Variasi } & \multicolumn{2}{l}{$\begin{array}{l}\text { Alfa } \\
\text { skala }\end{array}$ jikaskala } \\
& jikaKorelasi & \multicolumn{2}{c}{ Cronbach } \\
& item & item & \multicolumn{2}{c}{ total itemjika item } \\
terdeksi & dihapus & dikoreksi dihapus \\
\hline pk1 & 58,65 & 19,901 &, 332 &, 776 \\
pk2 & 58,59 & 19,637 &, 508 &, 760 \\
pk3 & 58,54 & 20,366 &, 341 &, 776 \\
pk4 & 58,59 & 20,637 &, 360 &, 771 \\
pk5 & 58,68 & 19,559 &, 331 &, 777 \\
pk6 & 58,05 & 18,719 &, 391 &, 765 \\
pk7 & 57,97 & 18,027 &, 642 &, 744 \\
pk8 & 57,95 & 18,719 &, 498 &, 756 \\
pk9 & 58,41 & 19,692 &, 329 &, 770 \\
pk10 & 57,86 & 18,065 &, 643 &, 744 \\
pk11 & 58,32 & 18,947 &, 325 &, 778 \\
pk12 & 58,49 & 19,535 &, 507 &, 760 \\
pk13 & 57,84 & 18,695 &, 516 &, 755 \\
pk14 & 58,08 & 18,299 &, 600 &, 748 \\
pk15 & 58,41 & 19,248 &, 345 &, 769 \\
\hline
\end{tabular}

Hasil yang diperoleh dari uji validitas adalah sebagai berikut:

Tabel 3.3.1. Uji reliabilitas motivasi

Reliability Statistics

Cronbach's Alpha N of Items

,767 19

Tabel 3.3.2. Uji reliabilitas motivasi

Reliability Statistics

Cronbach's Alpha $\mathrm{N}$ of Items

, 843

17

Tabel 3.3.3 Uji reliabilitas produktivitas

Reliability Statistics

\begin{tabular}{ll}
\hline Cronbach's Alpha N of Items \\
\hline 778 & 15 \\
\hline
\end{tabular}

Uji normalitas digunakan untuk menguji apakah dalam model regresi distribusi sebuah data mengikuti atau mendekati distribusi normal, yakni distribusi data dengan bentuk lonceng.

Salah satu cara untuk melihat normalitas adalah dengan melihat grafik histogram, dan grafik normal p-p plot, yang membandingkan antara dua observasi dengan distribusi yang mendekati distribusi normal. Hasil output SPSS terlihat seperti Gambar 3.4.1.1.1, dan 3.4.1.1.2. berikut:

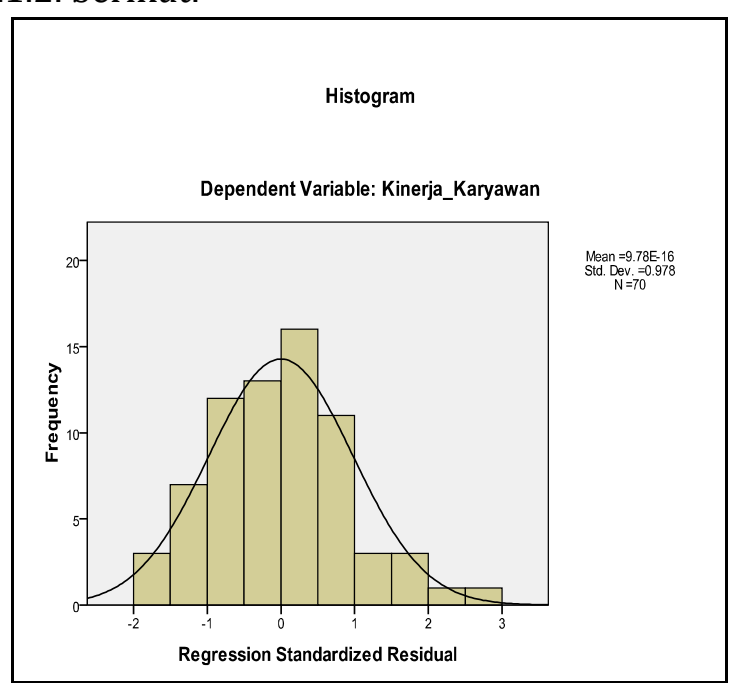

Sumber: Hasil Penelitian, 2017 (data diolah)

Gambar 3.4.1.1.2. Pengujian Normalitas Histogram

Pada hasil uji normalitas histogram dapat dilihat grafik tidak melenceng ke kiri maupun ke kanan, data berbentuk kurva yang seimbang sehingga membentuk gambar lonceng. Pada Gambar 3.4.1.1.2 terlihat bahwa bentuk kurva tidak melenceng ke kiri maupun ke kanan sehingga dapat dinyatakan normal.

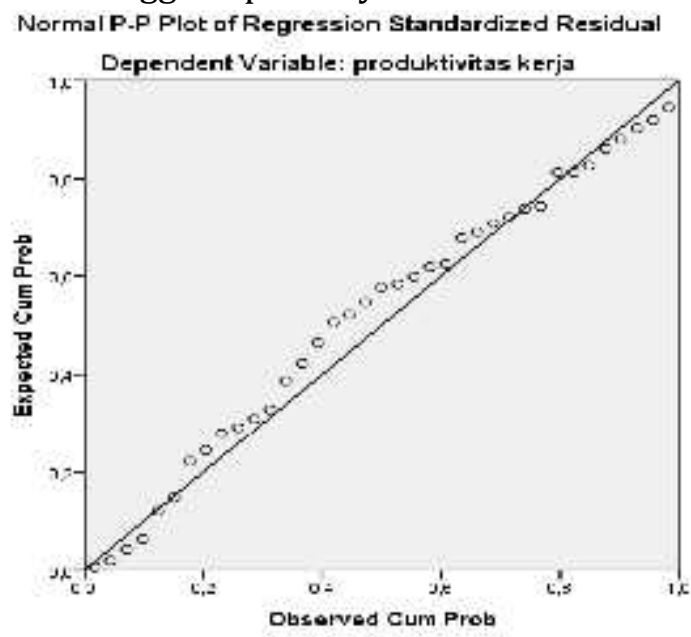

Sumber: Hasil Penelitian, 2017 (data diolah)

Gambar 3.4.1.1.2. Uji normalitas p-p plot

Pada P-P plot terlihat bahwa titik-titik menyebar disekitar garis diagonal dan cenderung mengikuti arah garis diagonal. Hal ini menunjukkan bahwa data yang 
dipergunakan dalam penelitian ini memenuhi asumsi normalitas sehingga layak untuk diuji dengan model regresi.

Uji normalitas dengan grafik bisa saja terlihat berdistribusi normal, padahal secara statistik tidak berdistribusi normal. Jika nilai sig probability lebih besar dari 0,05 maka Ho ditolak dengan pengertian bahwa data yang

Tabel 3.4.1.2. Uji Kolmogrov-Smirnov dianalisis berdistribusi normal. Demikian juga sebaliknya jika nilai sig probability lebih kecil dari 0,05 maka Ho diterima dengan pengertian bahwa data yang dianalisis tidak berdistribusi normal. Berikut ini pengujian normalitas yang didasarkan dengan uji statistik nonparametik Kolmogorv-Smirnov (K-S).

Tes One-Sample Kolmogorov-Smirnov

\begin{tabular}{lll}
\hline & & $\begin{array}{l}\text { Unstandardized } \\
\text { Residual }\end{array}$ \\
\hline $\mathrm{N}$ & & 37 \\
Parameter Normala,b & $\begin{array}{l}\text { Rata-Rata } \\
\text { Standar Deviasi }\end{array}$ &, 0000000 \\
Perbedaan Paling Ekstrim & Mutlak &, 101 \\
& Positif &, 050 \\
& Negatif &,- 101 \\
Statistik Tes & &, 101 \\
Asymp. Sig. (2-tailed) & &, $200^{\mathrm{c}, \mathrm{d}}$ \\
\hline
\end{tabular}
a. Pengujian distribusi adalah normal.
b. Dihitung dari data.
c. Koreksi signifikansi Lilliefors.
d. Ini adalah batas bawah dari makna sebanarnya.

Sumber: Hasil Penelitian, 2017 (data diolah)

Berdasarkan Tabel 3.4.1.2. terlihat bahwa nilai Asymp.Sig. (2-tailed) adalah 0,200 ini berarti nilainya diatas nilai signifikan $5 \%$ (0.05). dengan kata lain variabel tersebut berdistribusi normal.

Uji Heteroskedastisitas bertujuan untuk menguji apakah didalam model regresi terjadi ketidaksamaan varians. Model regresi yang baik adalah yang homoskedastisitas atau tidak terjadi heteroskedastisitas. Ada beberapa cara untuk mendeteksi ada atau tidaknya heteroskedastisitas, yaitu:

Dasar analisis adalah tidak ada pola yang jelas, serta titik-titik menyebar di atas dan di bawah angka 0 pada sumbu $Y$, maka tidak terjadi heteroskedastisitas, sedangkan jika ada pola tertentu, seperti titik-titik yang membentuk pola tertentu yang teratur, maka mengindikasikan telah terjadi heteroskedastisitas.

Berdasarkan Gambar 3.4.2.1. dapat terlihat bahwa tidak ada pola yang jelas, serta titik-titik menyebar di atas dan dibawah angka
0 pada sumbu Y, maka berdasarkan metode grafik tidak terjadi heteroskedastisitas pada model regresi.

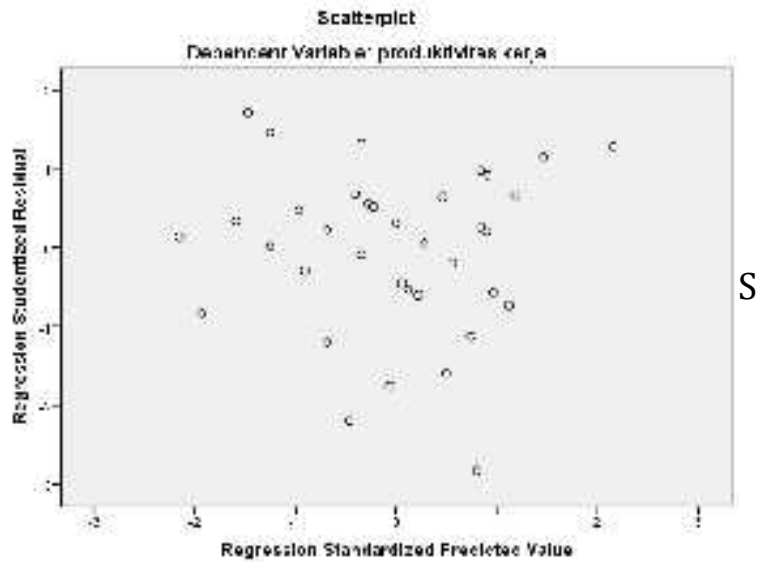

Sumber: Hasil Penelitian, 2017 (data diolah)

Gambar 3.4.2.1. Uji heteroskedastisitas

Dasar analisis metode statistik adalah jika variabel bebas signifikan secara statistik mempengaruhi variabel terikat, maka $t$ indikasi terjadi heteroskedastisitas. 
Tabel 3.4.2.2.Uji Glejser

Koefisien $^{\mathrm{a}}$

\begin{tabular}{llllll}
\hline \multirow{2}{*}{ Model } & \multicolumn{2}{l}{ Koefisien Tidak Standar } & \multicolumn{2}{l}{ Koefisien Standar } & \\
\cline { 2 - 6 } & $\mathrm{B}$ & Std. Error & Beta & $\mathrm{t}$ & Sig. \\
\hline $1 \quad$ Konstan) &,- 349 &, 480 & &,- 728 &, 472 \\
\multicolumn{1}{l}{ Motivasi Kerja } &, 074 &, 098 &, 131 &, 755 &, 456 \\
\multicolumn{1}{l}{ Kepuasan } &, 022 &, 074 &, 052 &, 300 &, 766 \\
\hline
\end{tabular}

Variabel Dependen: absres

Sumber: Hasil Penelitian, 2017 (data diolah)

Berdasarkan Tabel 3.4.2.2. dapat diketahui bahwa tidak satupun variabel bebas yang signifikan secara statistik mempengaruhi variabel terikat. Hal ini terlihat dari probabilitas signifikansinya di atas tingkat kepercayaan $5 \%$ jadi disimpulkan model regresi tidak mengarah adanya heteroskedastisitas.

Uji Multikolinieritas, Gejala multikolinieritas dapat dilihat dari besarnya nilai Tolerance dan VIF (Variance Inflation Factor), Kedua ukuran ini menunjukkan setiap variabel independen manakah yang dijelaskan oleh variabel independen lainnya, Tolerance adalah mengukur variabilitas variabel independen yang terpilih yang tidak dijelaskan variabel independen lainnya. Nilai yang dipakai untuk Tolerance $>0,1$, dan VIF $<5$, maka tidak terjadi multikolinieritas.
Tabel 4.4.3. Uji multikolinieritas

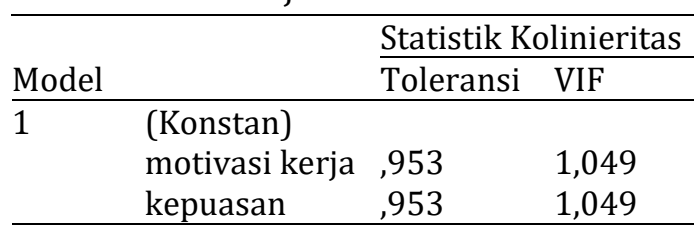

Sumber: Hasil Penelitian, 2017 (data diolah)

Berdasarkan Tabel 3.4.3. dapat terlihat bahwa data (variabel) tidak terkena multikolinieritas karena nilai VIF $<5$ dan nilai Tolerance $>0,1$ sehingga model regresi layak dipakai untuk memprediksi kinerja karyawan berdasarkan masukan variabel motivasi dan kepuasan kerja.

Regresi Linier Berganda, Analisis regresi linier berganda dilakukan dengan bantuan SPSS 19.0 dengan tujuan untuk mengetahui seberapa besar pengaruh variabel bebas yang terdiri dari motivasi dan kepuasankerja terhadap variabel terikat yaitu produktivitas kerja. Berdasarkan Tabel 3.4.4.1. (Variabel Entered/removed ${ }^{b}$ ) menunjukkan hasil analisis statistik tiap indikator sebagai berikut:

Tabel 3.4.4.1.Analisis regresi linier berganda

Coefficients $^{\mathrm{a}}$

\begin{tabular}{|c|c|c|c|c|c|c|c|}
\hline \multirow[b]{2}{*}{ Model } & \multicolumn{2}{|c|}{ Koefisien Tidak Standar } & \multicolumn{3}{|c|}{ Koefisien Standar } & \multicolumn{2}{|c|}{ Statistik Kolinieritas } \\
\hline & $\mathrm{B}$ & Std. Error & Beta & $\mathrm{t}$ & Sig. & & $\mathrm{B}$ \\
\hline $\begin{array}{ll}1 & \text { (Constant) }\end{array}$ &, 059 & 803 & & 074 & 1 & (Constant) & 059 \\
\hline motivasi kerja & ,551 & 164 & 437 & 3,358 & & $\begin{array}{l}\text { motivasi } \\
\text { keria }\end{array}$ & ,551 \\
\hline kepuasan & ,406 & ,124 & ,424 & 3,260 & & kepuasan & ,406 \\
\hline
\end{tabular}

Variabel Dependen : produktivitas kerja

Sumber: Hasil Penelitian, 2017 (data diolah)

Berdasarkan Tabel 4.4.4.1. maka persamaan analisis regresi linier berganda dalam penelitian ini adalah:

$$
\mathrm{Y}=0,059+0,551 \mathrm{X}_{1}+0,406 \mathrm{X}_{2}
$$

3.5. Uji Hipotesis
Uji Signifikan Simultan (Uji-F), Pengujian ini dilakukan untuk melihat apakah semua variabel bebas yang dimasukkan dalam model mempunyai pengaruh secara bersama-sama terhadap variabel terikat. 
Tabel 3.5.1. Hasil uji signifikan simultan (uji-F)

ANOVA $^{\text {a }}$

\begin{tabular}{lllllll}
\hline Model & & Jumlah Kuadrat & Df & Mean Square & F & Sig. \\
\hline 1 & Regresi &, 259 & 2 &, 129 & 13,964 &, $000^{\mathrm{b}}$ \\
& Residual &, 315 & 34 &, 009 & & \\
& Total &, 574 & 36 & & & \\
\hline
\end{tabular}

a. Variabel Dependen : produktivitas kerja

b. Prediktor : (Konstan), kepuasan, motivasi kerja

Sumber: Hasil Penelitian, 2017 (data diolah)

Pada Tabel 3.5.1. dapat dilihat bahwa (motivasi kerja dan kepuasan kerja) secara hasil perolehan $\mathrm{F}_{\text {hitung }}$ pada tingkat signifikansi serempak adalah signifikan terhadap variabel $=0.000$, lebih besar dari nilaiF tabelyakni 2,744, terikat (produktivitas kerja).

dengantingkat kesalahan $\alpha=5 \%$, atau dengan Uji Signifikan Parsial (Uji-t), Pengujian kata lain $\quad \mathrm{F}_{\text {hitung }}>\mathrm{F}_{\text {tabel }}$ ini dilakukan untuk mengetahui seberapa jauh $(13,964>2,744)$.Berdasarkan kriteria pengaruh suatu variabel bebas secara parsial pengujian hipotesis jika $F_{\text {hitung }}>F_{\text {tabel }}$ dan (individual) terhadap variasi variabel terikat tingkatsignifikansinya $\quad(0.000<\quad 0.05), \quad$ kerja) terhadap variabel terikat (produktivitas menunjukkan bahwa pengaruh variabel bebas kerja).

Tabel 3.5.2. Hasil uji signifikan parsial (uji-t)

Coefficients $^{\mathrm{a}}$

\begin{tabular}{|c|c|c|c|c|c|c|c|c|}
\hline \multirow{2}{*}{\multicolumn{2}{|c|}{ Model }} & \multicolumn{2}{|l|}{$\begin{array}{l}\text { Koefisien } \\
\text { Standar }\end{array}$} & \multicolumn{2}{|c|}{ TidakKoefisien } & \multirow[b]{2}{*}{ Sig. } & \multicolumn{2}{|c|}{ Statistik Kolinearitas } \\
\hline & & $\mathrm{B}$ & Std. Error & Beta & $\mathrm{t}$ & & & $\mathrm{B}$ \\
\hline 1 & (Konstan) & 059 & ,803 & & 074 & \multirow[t]{2}{*}{1} & \multirow{2}{*}{$\begin{array}{l}\text { (Konstan) } \\
\text { Motivasi } \\
\text { Kerja }\end{array}$} & 059 \\
\hline & Motivasi Kerja & 551 & , 164 & ,437 & 3,358 & & & ,551 \\
\hline & Kepuasan &, 406 & ,124 & , 424 & 3,260 & & Kepuasan & ,406 \\
\hline
\end{tabular}

a. Variabel Dependen : produktivitas kerja

Sumber: Hasil Penelitian, 2017 (data diolah)

Uji Koefesien Determinasi $\left(\mathrm{R}^{2}\right)$, Pengujian koefisien determinasi berkisar antara nol sampai satu $\left(0 \leq R^{2} \geq 1\right)$. Jika $R^{2}$ semakin besar (mendekati satu), maka pengaruh variabel bebas (X) adalah besar terhadap variabel terikat (Y). Semakin kuat untuk menerangkan pengaruh variabel bebas terhadap variabel terikat dan demikian sebaliknya.

Tabel 3.6. Hasil uji koefesien determinasi $\left(\mathrm{R}^{2}\right)$ Ringkasan Model $^{\mathrm{b}}$

\begin{tabular}{lllll} 
Model & $\mathrm{R}$ & R Kuadrat & $\begin{array}{l}\text { Kuadrat } \\
\text { Disesuaikan }\end{array}$ & $\begin{array}{c}\text { REstimasiStd. } \\
\text { Error }\end{array}$ \\
\hline 1 &, $672^{\mathrm{a}}$ &, 451 &, 419 &, 09625 \\
\hline
\end{tabular}

a. Prediktor: (Konstan), kepuasan, motivasi kerja

b. Variabel : produktivitas kerja

Sumber: Hasil Penelitian, 2017 (data diolah) 
Hasil pengujian mengenai pengaruh motivasi kerjaterhadap produktivitas kerja secara parsial mempunyai pengaruh positif signifikan berdasarkan hasil uji $t=3,358$ dengan nilai p sebesar $0,002(<0,05))$ dimana nilai $\mathrm{t}$ hitung lebih besar dari t tabel yaitu 1,690 (taraf 5\%=0,05) dan 2,71948 (taraf $1 \%=0,010$ ) tersebut menandakan bahwa variabel motivasi kerja berpengaruh secara signifikan terhadap produktivitas kerja. Nilai koefisien regresi sebesar 0,551 yang menunjukkan motivasi kerja karyawan akan mempengaruhi produktivitas kerja.Dari hasil analisis yang diperoleh dapat disimpulkanfaktor motivasi kerjakaryawan memiliki pengaruh yang signifikan terhadap produktivitas kerja karyawan.Hal ini sesuai dengan pernyataan Herzberg, faktor motivasional antara lain pekerjaan seseorang, keberhasilan yang diraih, kesempatan bertumbuh, kemajuan dalam karir dan pengakuan orang lain. Berdasarkan hasil tersebut terlihat jelas bahwa motivasi sangat mempengaruhi produktivitas kerja karyawan karena dengan motivasi yang dimiliki oleh setiap masing-masing karyawan, dapat mendorong diri karyawan untuk bekerja lebih giat dan tekun demi meningkatkan produktivitas kerja dan meningkatkan target dari tujuan perusahaan, sehingga dengan demikian motivasi dan produktivitas saling berkaitan dan berhubungan demi mencapai kemajuan perusahaanMenurut Sugiyono (2008) uji $t$ berfungsi untuk mengetahui hubungan antara variabel bebas (independen) terhadap variabel terikat (dependen) yang akan diteliti, apakah hipotesisnya diterima atau ditolak.Hasil yang positif menunjukkan bahwa semakin tinggi motivasi kerja maka semakin tinggi tingkat produktivitas kerja yang dihasilkankaryawan tersebut, terutama sebagian dari responden setuju pada pernyataan tertantang melakukan pekerjaan dengan tingkat kesulitan yang tinggi, pekerjaan bersifat baru, rasa keingintahuan yang tinggi, mengembangkan kreatifitas dan produktivitas dalam bekerja. Motivasi dapat dilihat dari partisipasi karyawan dalam mengambil keputusan dan memberika masukan positif bagi perusahaan.

Hasil pengujian mengenai pengaruh kepuasan kerjaterhadap produktivitas kerja secara parsial mempunyai pengaruh positif signifikan terhadap produktivitas kerja berdasarkan hasil uji $t=3,260$ dengan nilai $p$ sebesar 0,003 $(<0,05)$ dimana nilai $\mathrm{t}$ hitung lebih besar dari $\mathrm{t}$ tabel yaitu 1,690 (taraf $5 \%=0,05$ ) dan 2,71948 (taraf $1 \%=0,010$ ) tersebut menandakan bahwa variabel motivasi kerja berpengaruh secara signifikan terhadap produktivitas kerja. dan nilai koefisien regresi sebesar 0,406 yang menunjukkan kepuasan kerja karyawan akan mempengaruhi produktivitas kerja.Dari hasil analisis yang diperoleh dapat disimpulkan faktor kepuasan kerja karyawan memiliki pengaruh yang signifikan terhadap produktivitas kerja karyawan. Hal ini sesuai dengan pernyataanHariandja (2007), kepuasan kerja dapat mempengaruhi perilaku kerja seperti absensi, malas, rajin, produktif dan lain-lain, atau mempunyai hubungan dengan beberapa jenis perilaku yang sangat penting dalam organisasi.

Hasil pengujian mengenai pengaruh motivasi dan kepuasan kerjaterhadap produktivitas kerja secara simultan (nersamasama) mempunyai pengaruh signifikanterhadap produktivitas kerja berdasarkan hasil uji $\mathrm{F}=13,964$ dengan nilai $\mathrm{p}$ sebesar $0,000(<0,05)$ dimana nilai $F$ hitung lebih besar dari $F$ tabel yaitu 3,28 (taraf $5 \%=0,05$ ) dengan nilai df (pembilang N1) regresi 2 dan df (penyebut N2) residual 34 pada tabel F. Hasil ini menunjukkan semakin tinggi motivasi karyawan akan meningkatkan produktivitas karyawan BPJS, sebaliknya semakin tinggi kepuasan kerja karyawan akan meningkatkan produktivitas kerja karyawan BPJS.

Dari hasil analisis yang diperoleh dapat disimpulkan faktor kepuasan kerja karyawan memiliki pengaruh yang signifikan terhadap produktivitas kerja karyawan. Pengujian 
Adjusted $\mathrm{R}$ square (koefisien determinasi) sebesar 0,451 , berarti terdapat dua variabel tidak terikat yaitu yaitu motivasi kerja $\left(\mathrm{X}_{1}\right)$ dan kepuasan kerja $\left(\mathrm{X}_{2}\right)$ hanya berpengaruh sebesar $45,1 \%$ terhadap produktivitas sedangkan selebihnya yaitu sebesar 54,9\% dapat dipengaruhi atau dijelaskan oleh variabel-variabel lain yang tidak dimasukan dalam model penelitian ini selain variabel motivasi dan kepuasan. Motivasi dan kepuasan berpengaruh karyawan BPJS. Karyawan di BPJS memiliki motivasi kerja kategori tinggi, sedangkan tingkat kepuasan dan produktivitas kerja dalam kategori sangat tinggi. Hal ini sesuai dengan pernyataanMangkunegara (2008), motivasi adalah kondisi yang menggerakkan karyawan agar mampu mencapai tujuan dengan adanya dorongan dalam diri pada diri karyawan dapat menjadi suatu penopang keberhasilan suatu perusahaan karena adanya budaya pemberian penghargaan kepada karyawan yang berprestasi.

\section{SIMPULAN}

Adjusted R square (koefisien determinasi) sebesar 0,419 , berarti terdapat dua variabel tidak terikat yaitu yaitu motivasi kerja $\left(\mathrm{X}_{1}\right)$ dan kepuasan kerja $\left(\mathrm{X}_{2}\right)$ hanya berpengaruh sebesar $41,9 \%$ terhadap produktivitas sedangkan selebihnya yaitu sebesar 58,1\% dapat dipengaruhi atau dijelaskan oleh variabel-variabel lain yang tidak dimasukan dalam model penelitian ini selain variabel motivasi dan kepuasan. Variabel motivasi kerja secara parsial mempunyai pengaruh positif signifikan terhadap produktivitas kerja berdasarkan hasil uji $t=3,358$ dengan nilai $p$ sebesar 0,002 $(<0,05)$ dan nilai koefisien regresi sebesar 0,551 yang menunjukkan motivasi kerja karyawan akan mempengaruhi produktivitas kerja. Variabel kepuasankerja secara parsial mempunyai pengaruh positif signifikan terhadap produktivitas kerja berdasarkan hasil uji $t=3,260$ dengan nilai $p$ sebesar 0,003 $(<0,05)$ dan nilai koefisien regresi sebesar
0,406 yang menunjukkan kepuasan kerja karyawan akan mempengaruhi produktivitas kerja. Variabel motivasi kerja dan kepuasan kerja secara simultan (bersama-sama) memiliki pengaruh signifikanterhadap produktivitas kerja berdasarkan hasil uji $\mathrm{F}$ $=13,964$ dengan nilai p sebesar $0,000(<0,05)$ yang menunjukkan semakin tinggi motivasi karyawan akan meningkatkan produktivitas karyawan BPJS, sebaliknya semakin tinggi kepuasan kerja karyawan akan meningkatkan produktivitas kerja karyawan BPJS.

\section{DAFTAR PUSTAKA}

Bernardin, H. J.\& J. E.A. Russel. 2003. Human resource management (An Experimental Approach International Edition). Mc. GrawHill Inc.Singapore.

Börsch-supan, A., \& Weiss, M. 2016. The Journal of the Economics of Ageing Productivity and age: Evidence from work teams at the assembly line q. https://doi.org/10.1016/j.jeoa.2015.12.001.

Bridgman, B. 2015. Journal of Economic Dynamics \& Control Competition, work rules and productivity. Journal of Economic Dynamics and Control, 52, 136-149. https://doi.org/10.1016/j.jedc.2014.12.008.

Drucker, P. F. 1982. Pengantar Manajemen. Jakarta: PT Pustaka Binaman Pressindo.A. M. Sugeng Budiono. 2003. Bunga Rampai Hiperkes dan Keselamatan Kerja. Semarang: Badan Penerbit Universitas Diponegoro.

Follett, M. P. 1999. Visionary Leadership and Strategic Management.

Grifin, R.W. 2003. Manajemen. Jakarta: Erlangga.

Harindja, M. T.E. 2007. Manajemen Sumber Daya Manusia Pengadaan, Pengembangan, Pengkompensasian, dan Peningkatan Produktivitas Pegawai. Jakarta: Grasindo, PT. Gramedia. Daya Manusia Pengadaan, Pengembangan, Pengkompensasian, dan Peningkatan Produktivitas Pegawai. Jakarta: Grasindo, PT. Gramedia.

Kurniawan, B., 2012. Metodologi Penelitian. Jelajah Nusa. Tangerang.

Mangkunegara, A. P.2005. Manajemen Sumber Daya Manusia Perusahaan. Bandung: Remaja Rosdakarya.

Mathis, R. L. dan J. H. Jackson. 2002. Manajemen Sumber Daya Manusia Jilid 2. Jakarta: Grafindo.

MCB University Press. Women in Management Review Volume 14 . Number 7. 
Nurhayati, M. N., D, S. Z. M., \& Mahidzal, D. 2016. International Journal of Industrial Ergonomics The relationship between work productivity and acute responses at different levels of production standard times, 56. https://doi.org/10.1016/j.ergon.2016.09.00 9

Rivai, Veithzal, 2004. Manajemen Sumber Daya Manusia Untuk Perusahaan. Cetakan I, Murai Kencana. Jakarta.

Robbins, P. Sthepen dan Judge, A. Timothy. 2009. Perilaku Organisasi. Jakarta: Salemba Empat.

Robbins, S. P. 2008. Organizational Behavior. 11th edition. Alih Bahasa Drs. Benyamin Molan. Jakarta: PT. Macanan Jaya Cemerlang.

Robbins, S. 2006. Perilaku Organisasi. Alih Bahasa: Benyamin Molan. Edisi Kesepuluh. Jakarta: PT. Indeks, Kelompok Gramedia.

Sebastiano, A., Belvedere, V., Grando, A., \& Giangreco, A. 2016. The effect of capacity management strategies on employees 'wellbeing: A quantitative investigation into the long-term healthcare industry. European Management Journal, 1-11. https://doi.org/10.1016/j.emj.2016.12.001
Siagian, S. P. 2003. Manajemen Sumber Daya Manusia. Jakarta: Bumi Aksara.

Situmorang dan Lutfi. 2012. Pengolahan Data SPSS. Gramedia. Jakarta.

Sofyandi dan Garniwa. 2007. Perilaku Organisasional. Edisi Pertama. Graha Ilmu. Yogyakarta.

Sugiyono. 2008. Metode Penelitian Kuantitatif Kualitatif dan R\&D. Bandung: Alfabeta.

Syafrizal. 2008. Analisis Data Penelitian Menggunakan Program SPSS, Cetakan 1, USU Press, Medan.

Timpe, A. D. 1992. Seri Manajemen Sumber Daya Manusia Kinerja. Elex Media Komputindo. Jakarta.

Valero, D., \& Hirschi, A. 2016. Latent profiles of work motivation in adolescents in relation to work expectations; goal engagement; and changes in work experiences. Journal of Vocational Behavior. https://doi.org/10.1016/j.jvb.2016.01.003.

Záme, R. 2014. The measurement of employee motivation by using multi-factor statistical analysis, 109(1998), 851-857. https://doi.org/10.1016/j.sbspro.2013.12.5 53. 